\title{
Analisa Pengaruh Variasi Leaching dan Penambahan Template Terhadap Pembentukan Hollow Mesoporous Silika Nanopartikel
}

\author{
Ni Komang Alit Juliani, Hariyati Purwaningsih, Diah Susanti, dan Vania Mitha Pratiwi \\ Departemen Teknik Material dan Metalurgi, Fakultas Teknologi Industri, Institut Teknologi Sepuluh Nopember \\ (ITS) \\ e-mail: hariyati@mat-eng.its.ac.id
}

\begin{abstract}
Abstrak-Penelitian ini bertujuan untuk menganalisa pengaruh efektifitas leaching dalam menghasilkan silika, dan menganalisa pengaruh penambahan senyawa template OA (Octyl Amine) pada pembentukan mesopori silika nanopartikel Penelitian ini menggunakan bahan dasar sekam padi yang di leaching menggunakan asam kuat yaitu $\mathrm{HNO}_{3}$, $\mathrm{HCl}$, dan $\mathrm{H}_{2} \mathrm{SO}$. Berdasarkan hasil pengujian EDX kadar silika yang paling tinggi dihasilkan pada leaching menggunakan HNO3 sebesar 39.21 (wt\%). Gugus fungsi hasil FTIR menjelaskan adanya gugus siloksan. Hasil XRD menunjukkan bahwa silika mesopori silika nanopartikel hasil proses ekstraksi mempunyai fasa amorfus. Hasil SEM pada mesopori silika nanopartikel memiliki bentuk partikel yang lebih kecil dan penyebarannya merata. Dari hasil TEM didapatkan ukuran partikel pada mesopori silika nanopartikel berkisar antara $16-80 \mathrm{~nm}$. Mesopori silika nanopartikel memiliki diameter pori rata-rata sebesar 12.6 nm. Penggunaan OA berhasil untuk menyeragamkan ukuran partikel.
\end{abstract}

Kata Kunci-sekam padi, leaching, sol-gel, OA (Octyl Amine), silika mesopori.

\section{PENDAHULUAN}

B EBERAPA ratus tahun yang lalu para ilmuwan tertarik untuk meneliti pembuatan nanomaterial berpori. Penelitian yang dilakukan baik dalam hal bentuk, komposisi, dan struktur nanomaterial, serta sifat atau karakteristiknya. Aplikasi potensial dari nanomaterial di berbagai bidang dalam kehidupan sehari-hari, meliputi optik, elektronik, perangkat, sensor, katalis, dan obat-obatan [1]. Salah satu nanomaterial berpori adalah material mesopori yang memiliki ukuran diameter pori 2-50nm. Material mesopori seperti $\mathrm{SiO}_{2}$, $\mathrm{TiO}_{2}, \mathrm{ZnO}_{2}$, dan $\mathrm{Fe}_{2} \mathrm{O}_{3}$ [2]. Aplikasi yang umum digunakan dari material mesopori diantaranya sebagai katalis, bio-medis, material sensor, perangkat elektro-optik, dan teknologi elektronik [3].

Material mesopori dapat dibagi menjadi dua kategori, yakni famili material M41S dan material zeolit berpilar. Kedua material ini menunjukkan keragaman struktural dan komposisi yang luas dengan relatif mudahnya persiapan dalam hal proses pembuatan atau fabrikasinya, sehingga memberikan peluang baru untuk aplikasi sebagai katalis, penyerapan dan dukungan media yang digunakan [4].

Famili M41S memiliki keunikan karakteristik yang berbedabeda, misalnya saja MCM-41 memiliki susunan yang heksagonal dari porus 1-dimensional, MCM-48 menunjukkan struktur kubik, dan MCM-50 memiliki susunan lamellar [5].

Untuk mensintesis mesopori silika dapat dilakukan dengan beberapa metode diantaranya liquid-phase, sol-gel, cokondensasi, pertukaran ion, induksi listrik microwave [6]. Namun, metode yang umum digunakan adalah metode solgel. Surfaktan berfungsi sebagai pembentuk misel di dalam proses pembentukan mesoporus silika. [7] melakukan sebuah penelitian tentang bola berongga yang memiliki aplikasi potensial di bidang teknik karena morfologi dan struktur khusus mereka. Pori-pori di cangkang berongga bisa menjadi jalan bagi zat tamu masuk ke dalam atau keluar dari cekungan, memungkinkan bola berongga diterapkan di bidang adsorpsi, pemisahan, katalisis, reaktor mikro, kapsul, dll. Hal ini juga menunjukkan bahwa bola berongga memiliki sifat mekanik, akustik, optik, elektromagnetik dan termal yang unik, membuat bola berongga menarik sebagai bahan fungsional baru yang maju. Dalam pembuatan bola silika berongga menggunakan TEOS dan template octylamine (OA). Pada penelitian kali ini, untuk mensintesis silika nanopartikel menggunakan metode sol-gel. Bahan utama yang digunakan pada penelitian ini berasal dari sekam padi yang akan diekstraksi untuk mendapatkan serbuk silika dan dilanjutkan dengan proses pembuatan silika hollow mesopori nanopartikel dengan penambahan OA (Octyl Amine).

\section{METODE PENELITIAN}

\section{A. Proses Ekstraksi Silika}

Ekstraksi silika $\left(\mathrm{SiO}_{2}\right)$ dilakukan dengan cara meleaching sekam padi dengan $\mathrm{HNO}_{3} 2 \mathrm{M}, \mathrm{HCl} 2 \mathrm{M}$, dan $\mathrm{H}_{2} \mathrm{SO}_{4} 2 \mathrm{M}$ sebanyak $100 \mathrm{~mL}$ sambil dipanaskan dengan temperatur $90^{\circ} \mathrm{C}$ selama 2 jam. Kemudian dicuci hingga mencapai $\mathrm{pH} 7$ dan dibakar dalam muffle furnace $600^{\circ} \mathrm{C}$ selama 4 jam. Hasil pembakaran tersebut, abu sekam padi, sebanyak 4 gram direaksikan dengan $\mathrm{NaOH} 2 \mathrm{M}$ sebanyak $67 \mathrm{ml}$ dengan stirring $90^{\circ} \mathrm{C}$ selama 2 jam. Setelah itu dibiarkan mendingin dan disaring ampasnya menggunakan kertas saring. Larutan hasil saringan dititrasi dengan larutan $\mathrm{H}_{3} \mathrm{PO}_{4} 2 \mathrm{M}$ sedikit demi sedikit hingga $\mathrm{pH}$ mencapai 9. Setelah itu, dibiarkan 8 jam untuk proses aging.

Proses aging selesai, dimasukkan dalam mesin centrifuge dengan kecepatan putar sebesar $3000 \mathrm{rpm}$ selama 8 menit, kemudian dilanjutkan dengan mencuci endapan yang terbentuk dengan akuades. Endapan tersebut dicuci minimal 4 kali hingga mencapai $\mathrm{pH}=7$. Endapan tersebut kemudian 
dilakukan pengeringan (drying) dengan temperatur $100^{\circ} \mathrm{C}$ selama 2 jam. Hasil dari proses pengeringan tersebut diambil sampel kemudian dilakukan pengujian.

\section{B. Proses Pembuatan Hollow Silika Nanopartikel Mesopori}

Dalam tahap ini, bahan-bahan yang digunakan adalah silika hasil ekstraksi dari sekam padi $\left(\mathrm{SiO}_{2}\right)$, Natrium hidroksida $(\mathrm{NaOH})$, Asam klorida $(\mathrm{HCl})$, dan OA (Octyl Amine). 2 gram $\mathrm{SiO}_{2}$ dilarutkan dengan 2,64 gram $\mathrm{NaOH} 2 \mathrm{M}$ $33 \mathrm{~mL}$ diikuti dengan pengadukan selama 30 menit. Kemudian, larutan $\mathrm{Na}_{2} \mathrm{SiO}_{3}$ ditambahkan larutan Octyl Amine dengan cara meneteskan sedikit demi sedikit diikuti dengan pengadukan selama 1 jam. Setelah dilakukan pengadukan, menambahkan $\mathrm{HCl} 3 \mathrm{M}$ ke dalam campuran larutan hingga mencapai $\mathrm{pH}=10,2$ diikuti dengan pengadukan selama 5 menit. Kemudian, si filtrasi dan di cuci menggunakan akuades.

Setelah melakukan proses di atas, kemudian, endapan yang terbentuk dipisahkan dengan Buchner funnel dan endapan tersebut dicuci dengan akuades, serta dilakukan proses kalsinasi dengan temperature $550^{\circ} \mathrm{C}$ selama 6 jam.

\section{HASIL DAN DISKUSI}

\section{A. Hasil Pengujian FTIR}

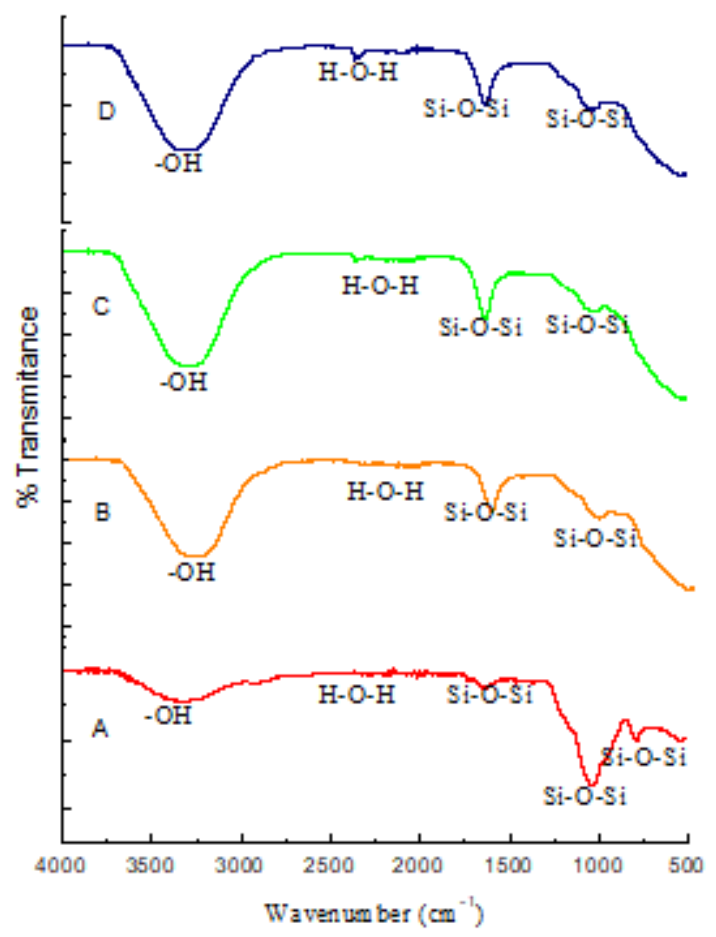

Gambar 1. Spektra FTIR dari sampel (A) sekam padi tanpa leaching, dan sekam padi setelah di leaching menggunakan (B) $\mathrm{HNO}_{3}$, (C) $\mathrm{HCl}$, (D) $\mathrm{H}_{2} \mathrm{SO}_{4}$

Gambar 1 menunjukkan spectra FTIR untuk masing-masing sampel. Proses leaching pada sekam padi menggunakan as am kuat yaitu $\mathrm{HNO}_{3}, \mathrm{HCl}$, dan $\mathrm{H}_{2} \mathrm{SO}_{4}$. Berdasarkan spectra FTIR dapat dilihat leaching efektif dilakukan untuk meningkatkan kadar Si-O-Si (siloksan) pada sekam padi. Terlihat pada sampel sekam padi tanpa leaching salah satunya dengan gugus fungsi Si-O-Si pada rentang bilangan gelombang $1634.33 \mathrm{~cm}^{-1}$ saat dilakukan leaching menggunakan $\mathrm{HNO}_{3}, \mathrm{HCl}$, dan $\mathrm{H}_{2} \mathrm{SO}_{4}$ gugus fungsi Si-O-Si meningkat pada rentang bilangan gelombang $1635.58 \mathrm{~cm}^{-1}$ $1636.76 \mathrm{~cm}^{-1}$.

Gambar 2. spectra FTIR dari sampel abu sekam padi hasil dari pembakaran dengan temperatur $600^{\circ} \mathrm{C}$. Terlihat bahwa pada sampel (A), (B), (C), dan (D) sama-sama memiliki puncak tertinggi dengan bilangan gelombang sekitar $1054 \mathrm{~cm}^{-1}$ yang merupakan gugus fungsi dari Si-O-Si (siloksan). Dimana gugus fungsi ini merupakan pita vibrasi ulur asimetri $\mathrm{Si}-\mathrm{O}$ pada ikatan Si-O-Si. Gambar 2 membuktikan bahwa pada proses pembakaran gugus fungsi $-\mathrm{OH}$ dan $\mathrm{H}-\mathrm{O}-\mathrm{H}$ menguap, maka dari itu pengaruh leaching pada sekam padi ini sudah tidak terlihat lagi setelah menjadi abu sekam padi.



Gambar 2. Spektra FTIR dari sampel (A) abu sekam padi tanpa leaching, dan setelah di leaching menggunakan (B) $\mathrm{HNO}_{3},(\mathrm{C}) \mathrm{HCl}$, (D) $\mathrm{H}_{2} \mathrm{SO}_{4}$

\section{B. Hasil Pengujian XRD}

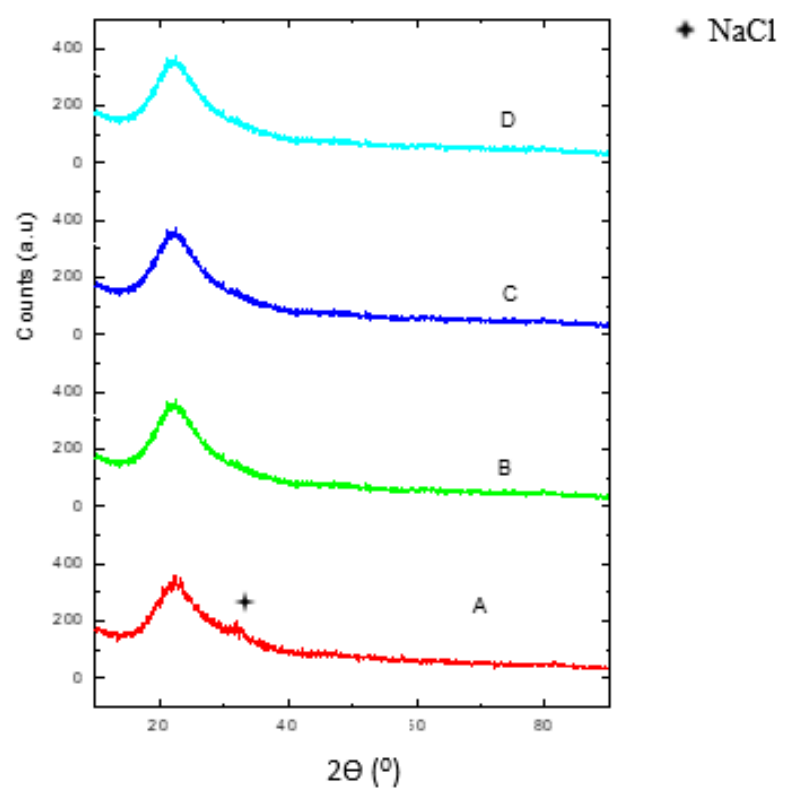

Gambar 3. Difraktogram XRD dari sampel (A) silika hasil ekstraksi sekam padi tanpa proses leaching, dan silika hasil ektraksi sekam padi dengan proses leaching (B) $\mathrm{HNO}_{3}$, (C) $\mathrm{HCl}$, dan (D) $\mathrm{H}_{2} \mathrm{SO}_{4}$ 
Gambar 3 menunjukkan difraktogram XRD dari beberapa sampel. Gambar 3 (A), memiliki merupakan silika hasil dari ekstraksi sekam padi tanpa leaching, yang mempunyai tinggi peak sekitar $400[\mathrm{cps}]$ dan nilai $2 \Theta$ sebesar $22.3601^{\circ}$. Pada sampel ini terlihat masih terdapat pengotor $\mathrm{NaCl}$ yang berasal dari proses pembuatan silika dari abu sekam padi. Peak NaCl telah dicocokkan berdas arkan PDF card ICCD \#00005-0628. Silika hasil ekstraksi sekam padi menggunakan proses leaching dengan $\mathrm{HNO}_{3}, \mathrm{HCl}$, dan $\mathrm{H}_{2} \mathrm{SO}_{4}$ ditunjukkan pada Gambar 3 (B), (C), dan (D), mempunyai tinggi peak sebesar $400[\mathrm{cps}]$ dan nilai $2 \Theta$ sekitar $22^{\circ}$.

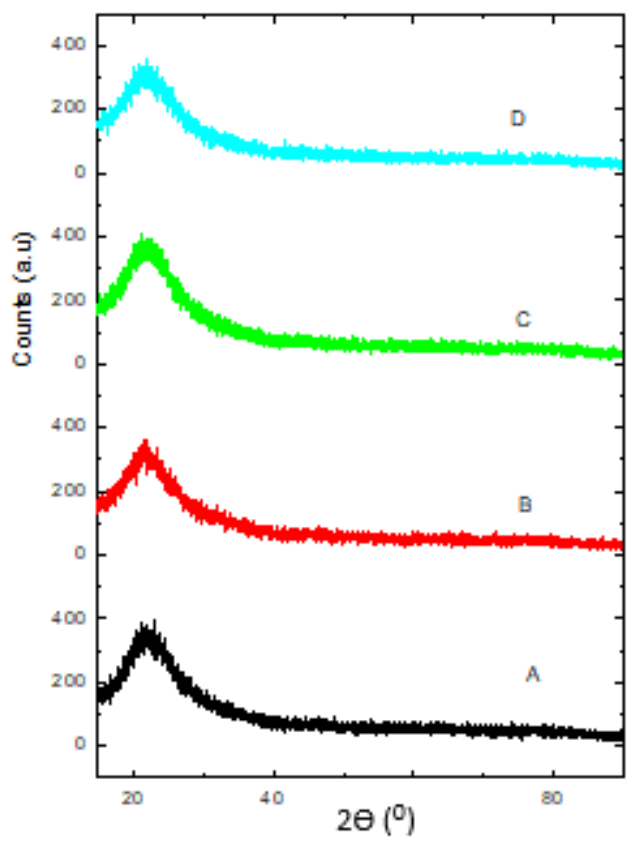

Gambar 4. Difraktogram setelah penambahan OA (Octyl Amine) pada silika (A) tanpa proses leaching, (B) leaching dengan $\mathrm{HNO}_{3}$, (C) leaching menggunakan $\mathrm{HCl}$, dan (D) leaching menggunakan $\mathrm{H}_{2} \mathrm{SO}_{4}$

Gambar 4. menunjukkan difraktogram dari sampel OA (Octyl Amine) dengan variasi leaching saat proses ekstraksi sekam padi. Gambar 4. (A), (B), (C), dan (D) sama-sama memiliki struktur Kristal amorfus yang memiliki nilai $2 \Theta$ sekitar 210 dan tinggi peak sebesar 400[cps]. Pada sampel penambahan OA ini memiliki struktur kristal amorfus yang seragam, karena tujuan penambahan OA ini untuk menyeragamkan ukuran pori. Sedangkan pada Tabel 4.2 menunjukkan ukuran Kristal dari silika berdasarkan hukum Bragg Scherrer.

Tabel 1 .

Ukuran Kristal penambahan OA (Octyl Amine)

\begin{tabular}{|c|c|c|c|c|c|c|c|c|}
\hline Sampel & $\begin{array}{c}\text { Pos. } \\
{[2 \theta]}\end{array}$ & $\begin{array}{c}\text { FWHM } \\
{\left[{ }^{\circ} 2 \theta\right]}\end{array}$ & $\overline{\mathrm{K}}$ & (A) & $\begin{array}{c}\mathrm{B} \\
\text { (rad) }\end{array}$ & $\cos \theta$ & $\begin{array}{c}d \\
\text { (A) }\end{array}$ & $\begin{array}{c}d \\
(n m)\end{array}$ \\
\hline OA & 21.5908 & 0.9792 & 0.90 & 1.5406 & 1.53 & 0.982 & 0.920 & 0.092 \\
\hline $\begin{array}{c}\mathrm{OA} \\
\mathrm{HNO}_{3}\end{array}$ & 21.6743 & 0.090 & 0.90 & 1.5406 & 0.1409 & 0.982 & 10.016 & 1.0016 \\
\hline $\begin{array}{c}\mathrm{OA} \\
\mathrm{HCl}\end{array}$ & 21.2853 & 0.090 & 0.90 & 1.5406 & 0.314 & 0.983 & 4.489 & 0.4489 \\
\hline $\begin{array}{c}\mathrm{OA} \\
\mathrm{H}_{2} \mathrm{SO}_{4}\end{array}$ & 21.4234 & 0.090 & 0.90 & 1.5406 & 1.533 & 0.982 & 0.920 & 0.0926 \\
\hline
\end{tabular}

\section{Hasil Pengujian EDX}

Proses leaching menggunakan $\mathrm{HNO}_{3}, \mathrm{HCl}$, dan $\mathrm{H}_{2} \mathrm{SO}_{4}$ pada sekam padi dapat meningkatkan kadar Silika. Berdasarkan perhitungan yield silika pada sekam padi menghasilkan kadar silika pada sekam padi dengan leaching menggunakan $\mathrm{HNO}_{3}$ sebesar 83.3\%, sedangkan menggunakan $\mathrm{HCl}$ sebesar $74.19 \%$, dan menggunakan $\mathrm{H}_{2} \mathrm{SO}_{4}$ sebesar $66.81 \%$. Maka dapat disimpulkan asam kuat yang cocok digunakan pada sekam padi untuk meningkatkan kadar silika yaitu HNO3 berdasakan perhitungan yield yang di dapatkan dalam data uji EDX sekam padi pada Tabel 2.

Tabel 2.

Komposisi unsur hasil pengujian EDX sekam padi dengan variasi leaching

\begin{tabular}{ccccc}
\hline \hline Element & $\begin{array}{l}\text { Sekam No } \\
\text { Leaching } \\
(\mathbf{w t} \%)\end{array}$ & $\begin{array}{l}\text { Sekam } \\
\text { Leaching } \\
\text { HNO }_{3} \text { (wt \%) }\end{array}$ & $\begin{array}{l}\text { Sekam } \\
\text { Leaching } \\
\text { HCl (wt \%) }\end{array}$ & $\begin{array}{l}\text { Sekam } \\
\text { Leaching } \\
\left.\mathbf{H}_{2} \text { SO }_{4} \text { (wt } \%\right)\end{array}$ \\
\hline $\mathrm{C}$ & 28.79 & 15.61 & 17.49 & 15.94 \\
$\mathrm{O}$ & 46.88 & 41.68 & 42.38 & 44.02 \\
$\mathrm{Na}$ & 0.37 & 0.19 & 0.32 & 0.53 \\
$\mathrm{Mg}$ & 0.48 & 0.17 & 0.23 & 0.19 \\
$\mathrm{Si}$ & 21.39 & 39.21 & 37.26 & 35.68 \\
$\mathrm{~S}$ & 0.22 & 0.95 & 0.63 & 0.4 \\
$\mathrm{~K}$ & 0.62 & 0.27 & 0.35 & 0.58 \\
$\mathrm{Ca}$ & 0.31 & 0.25 & 0.2 & 0.9 \\
$\mathrm{Ti}$ & 0.35 & 0.12 & 0.27 & 0.44 \\
$\mathrm{Fe}$ & 0.6 & 1.55 & 0.86 & 1.31 \\
\hline \hline
\end{tabular}

\section{Hasil Pengujian Mikroskop Elektronik}
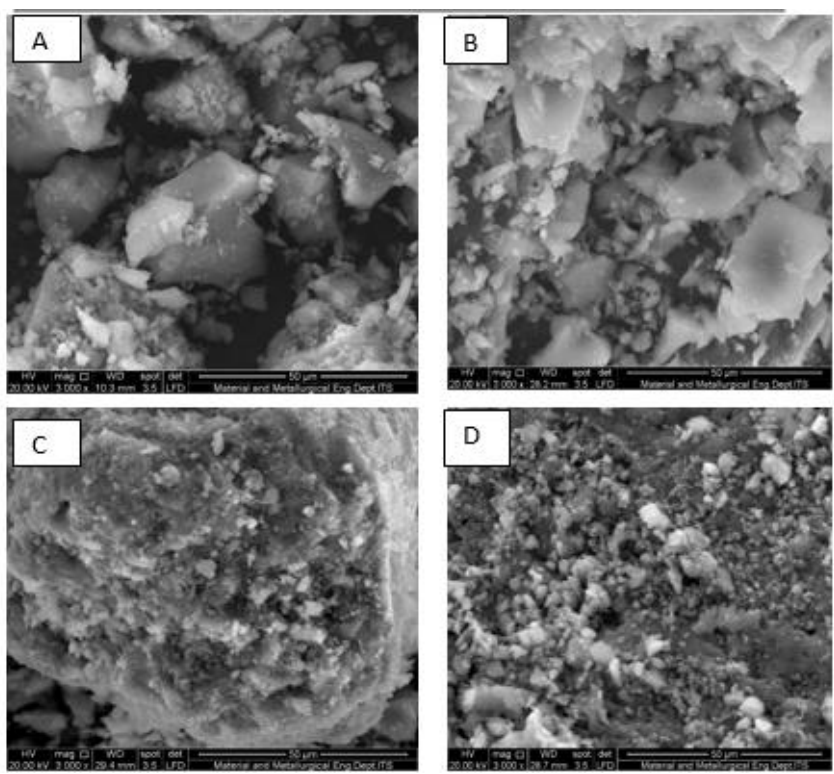

Gambar 5. Mikrografi hasil uji SEM dari sampel silika dengan pembesaran 3000x (A) silika tanpa proses leaching, (B) silika dengan leaching $\mathrm{HNO}_{3}$, (C) silika dengan leaching $\mathrm{HCl}$, dan (D) silika dengan leaching $\mathrm{H}_{2} \mathrm{SO}_{4}$

Gambar 5. menunjukkan mikrografi hasil uji SEM dari silika. Terlihat bahwa permukaan partikel dari silika tidak merata dan mempunyai ukuran yang besar dan mempunyai gumpalan (aglomerat), dan pada penelitian ini sesuai dengan penelitian yang dilakukan yang menyatakan morfologi silika yang berbentuk bulat [8]. 

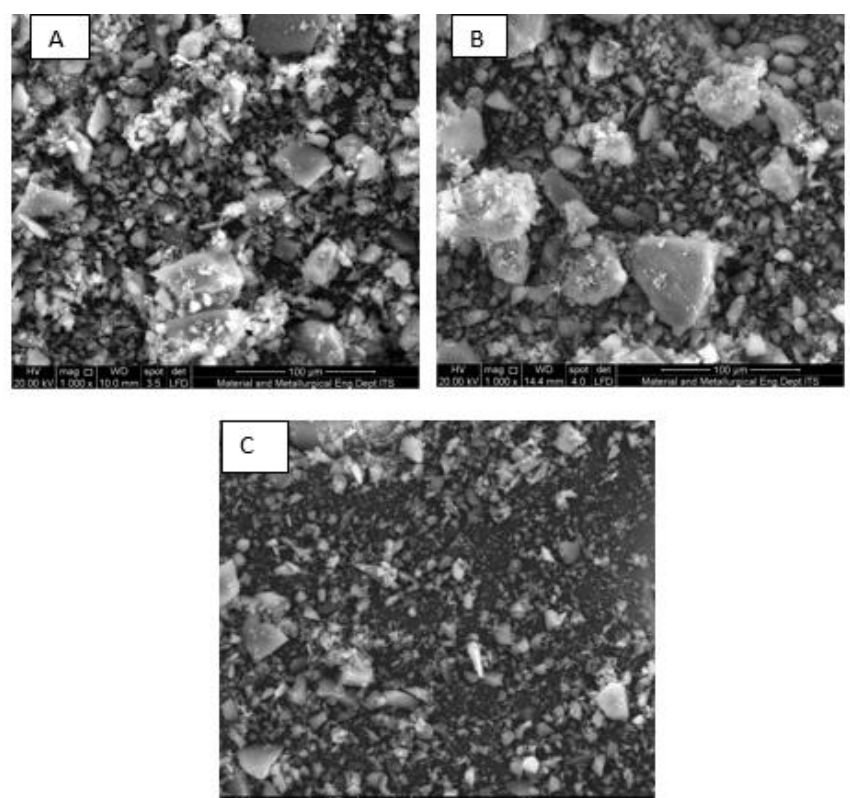

Gambar 6. Mikrografi hasil uji SEM dengan pembesaran 1000x dari penambahan OA (Octyl Amine) pada silika (A) leaching dengan $\mathrm{HNO}_{3}$, (B) leaching menggunakan $\mathrm{HCl}$, dan (C) leaching menggunakan $\mathrm{H}_{2} \mathrm{SO}_{4}$

Dari Gambar 6. terlihat dengan jelas bahwa permukaan sampel cukup merata dan hanya terdapat sedikit gumpalan (aglomerat), yang mengindikasikan adanya ukuran butir yang cukup beragam. Hal ini menunjukkan penambahan OA (Octyl Amine) dapat mempengaruhi ukuran pori pada $\mathrm{SiO} 2$.
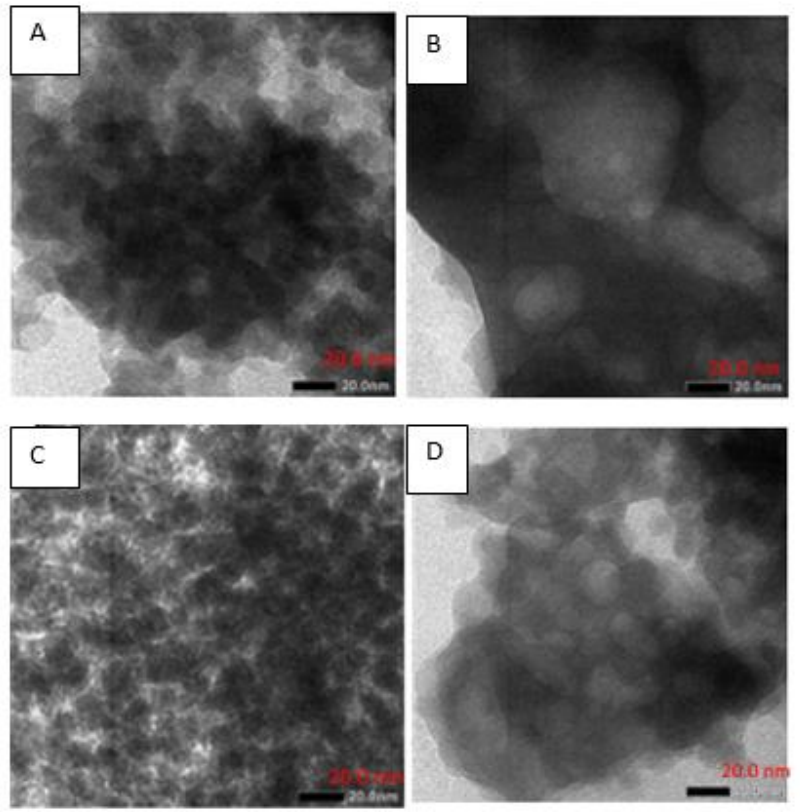

Gambar 7. Mikrografi TEM Silika pembesaran 80000x (A) Silika tanpa proses leaching, (B) Silika dengan leaching $\mathrm{HNO}_{3}$, (C) Silika dengan leaching $\mathrm{HCl}$, dan (D) Silika dengan leaching $\mathrm{H}_{2} \mathrm{SO}_{4}$

Secara umum partikel-partikel $\mathrm{SiO}_{2}$ memiliki ukuran partikel sekitar 50nm pada sampel (A), 18nm pada sampel (B), 20nm pada sampel (C), dan $18.7 \mathrm{~nm}$ pada sampel (D), ukuran partikel ini diperoh berdasarkan pengukuran menggunakan ruler image. Partikel-partikel ini membentuk gumpalan yang tidak beraturan dan bulat sehingga ketika diberikan transmisi electron diberikan gambar yang dihasilkan menjadi gelap.
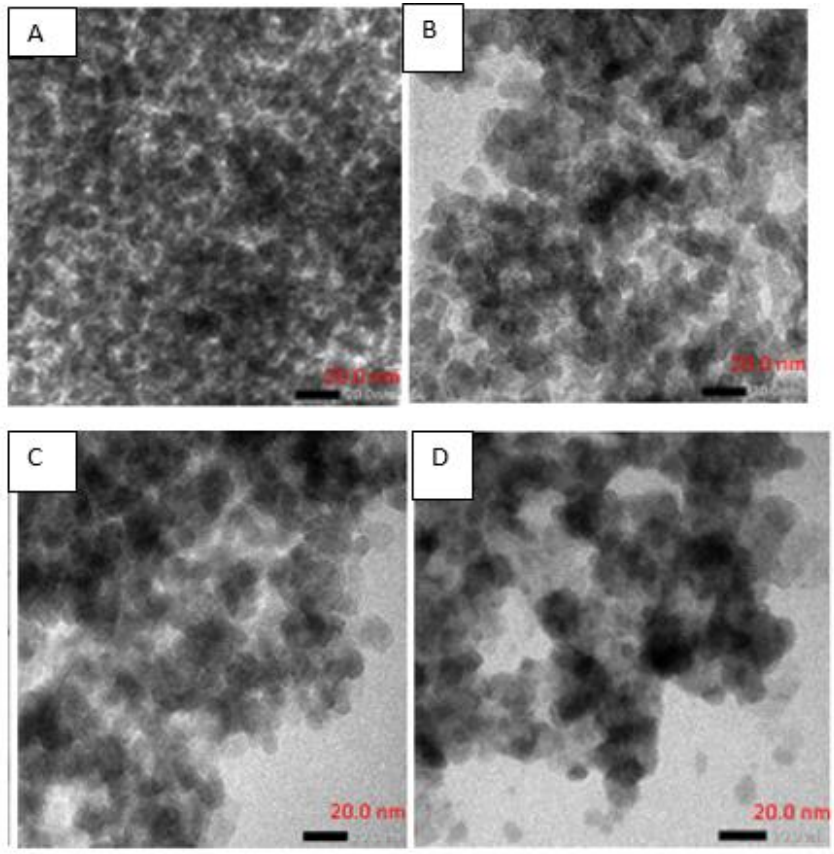

Gambar 8. Mikrografi TEM dari penambahan OA (Octyl Amine) dengan pembesaran 80000x (A) OA tanpa proses leaching, (B) OA dengan leaching $\mathrm{HNO}_{3}$, (C) $\mathrm{OA}$ dengan leaching $\mathrm{HCl}$, dan (D) $\mathrm{OA}$ dengan leaching $\mathrm{H}_{2} \mathrm{SO}_{4}$

Gambar 8. (A) menunjukkan mikrografi TEM dari silika tanpa leaching dengan penambahan OA (Octyl Amine) yang mempunyai bentuk partikel sedikit beraturan, terang, dan mempunyai ukuran ukuran rata-rata partikel $40 \mathrm{~nm}$. Gambar 8. (B) menunjukkan mikrografi TEM dari silika leaching $\mathrm{HNO}_{3}$ dengan penambahan OA (Octyl Amine) yang mempunyai bentuk partikel lebih beraturan, terang, pipih dan mempunyai ukuran ukuran rata-rata partikel 15.8 nm. Gambar 8. (C) menunjukkan mikrografi TEM dari silika leaching $\mathrm{HCl}$ dengan penambahan OA (Octyl Amine) yang mempunyai bentuk partikel lebih beraturan, terang, pipih dan mempunyai ukuran ukuran rata-rata partikel $18.3 \mathrm{~nm}$. Gambar 8. (D) menunjukkan mikrografi TEM dari silika leaching $\mathrm{H}_{2} \mathrm{SO}_{4}$ dengan penambahan $\mathrm{OA}$ (Octyl Amine) yang mempunyai bentuk partikel lebih beraturan, terang, pipih dan mempunyai ukuran ukuran rata-rata partikel $16.7 \mathrm{~nm}$.

Dari semua sampel maka dapat disimpulkan, silika dengan penambahan OA (Octyl Amine) mempunyai partikel yang beraturan, pipih, dan tidak menggumpal sehingga ketika diberikan transmisi electron diberikan gambar yang dihasilkan menjadi lebih terang dibanding gambar yang dihasilkan pada Gambar 7.

\section{E. Hasil Pengujian BET Surface Analysis}

Luas permukaan pada silika gel sebesar $163 \mathrm{~m}^{2} / \mathrm{g}$ [8]. Untuk penelitian ini di dapatkan data uji BET seperti Tabel 4.4. Dari data tersebut di peroleh untuk sampel $\mathrm{SiO} 2$ dengan leaching $\mathrm{HNO}_{3}$ dan $\mathrm{H}_{2} \mathrm{SO}_{4}$ sama-sama memiliki diameter pori sekitar $18.1 \mathrm{~nm}$, sedangkan pada sapel $\mathrm{SiO}_{2}$ tanpa leaching memiki jar-jari pori sebesar $259.802 \AA ̊$ dan pada $\mathrm{SiO}_{2}$ dengan leaching $\mathrm{HCl}$ mempunyai jari-jari pori sebesar 15.404 .

Berdasakan hasil pengujian BET pada sampel penambahan OA (Octyl Amine) didapatkan data seperti Tabel 4.5. Pada sampel penambahan $\mathrm{OA}$ pada hasil leaching menggunakan $\mathrm{HNO}_{3}, \mathrm{HCl}$ dan $\mathrm{H}_{2} \mathrm{SO}_{4}$ memiliki jari-jari pori sekitar $63 \AA$, 
sedangkan pada sampel penambahan OA pada hasil leaching menggunakan $\mathrm{HNO}_{3}$ memiliki jari-jari sebesar $75 \AA ̊$.

Tabel 3 .

Data ukuran surface area, volume pori, dan jari-jari pori dari sampel $\mathrm{SiO}_{2}$

\begin{tabular}{|c|c|c|c|}
\hline Sampel & $\begin{array}{l}\text { Surface } \\
\left(\mathrm{m}^{2} / \mathrm{g}\right)\end{array}$ & $\begin{array}{c}\text { Volume } \\
\text { Pori } \\
\text { (cc/g) }\end{array}$ & $\begin{array}{c}\text { Diameter } \\
\text { Pori } \\
\text { (nm) }\end{array}$ \\
\hline $\begin{array}{l}\mathrm{SiO}_{2} \text { tanpa } \\
\text { leaching }\end{array}$ & 247.647 & 2.972 & 51.3604 \\
\hline $\begin{array}{c}\mathrm{SiO}_{2} \text { leaching } \\
\mathrm{HNO}_{3}\end{array}$ & 210.462 & 1.463 & 18.1266 \\
\hline $\mathrm{SiO}_{2}$ leaching & 1.594 & 1.690 & 3.0808 \\
\hline $\mathrm{HCl}$ & & & \\
\hline $\begin{array}{c}\mathrm{SiO}_{2} \text { leaching } \\
\mathrm{H}_{2} \mathrm{SO}_{4}\end{array}$ & 64.051 & 0.618 & 18.1492 \\
\hline
\end{tabular}

Tabel 4.

Data ukuran surface area, volume pori, dan jari-jari pori dari sampel $\mathrm{OA}($ Octyl Amine)

\begin{tabular}{|c|c|c|c|}
\hline Sampel & $\begin{array}{c}\text { Surface } \\
\left(\mathrm{m}^{2} / \mathrm{g}\right)\end{array}$ & $\begin{array}{c}\text { Volume } \\
\text { pori } \\
(\mathrm{cc} / \mathrm{g})\end{array}$ & $\begin{array}{c}\text { Diameter } \\
\text { pori } \\
(\mathrm{nm})\end{array}$ \\
\hline $\begin{array}{c}\text { OA leaching } \\
\mathrm{HNO}_{3}\end{array}$ & 305.494 & 1.451 & 15.04 \\
\hline $\begin{array}{c}\text { OA leaching } \\
\mathrm{HCl}\end{array}$ & 18.853 & 1.225 & 12.72 \\
\hline $\begin{array}{c}\text { OA leaching } \\
\mathrm{H}_{2} \mathrm{SO}_{4}\end{array}$ & 148.066 & 0.799 & 12.62 \\
\hline
\end{tabular}

\section{KESIMPULAN}

1. Sintesa silika dari sekam padi menghasilkan material mesoporous silika nanopartikel. Pada proses sintesa, sekam padi di leaching menggunakan $\mathrm{HNO}_{3}, \mathrm{HCl}$, dan $\mathrm{H}_{2} \mathrm{SO}_{4}$ dimana dalam proses leaching ini mengkasilkan kadar silika yang berbeda beda berdasarkan perhitungan rata-rata kadar silika dalam sekam padi berdasarkan hasil uji EDX. Saat sekam padi di leaching menggunakan $\mathrm{HNO}_{3}$ memiliki kadar silika sebesar $83.3 \%$, sedangkan menggunakan $\mathrm{HCl}$ sebesar $74.19 \%$, dan saat menggunakan $\mathrm{H}_{2} \mathrm{SO}_{4}$ sebesar $66.81 \%$. Berdasarkan hasil rata-rata perhitungan kadar silika dalam sekam padi menunjukkan bahwa sekam padi dengan leaching menggunakan $\mathrm{HNO}_{3}$ lebih efektif untuk meningkatkan kadar silika. Hasil dari sintesa silika menghasilkan fasa amorf dan memiliki ukuran partikel sebesar $18 \mathrm{~nm}-50$ nm. Selain itu , karakteristik dari material silika tersebut menghasilkan ukuran distribusi partikel yang lebih homogen. Ukuran diameter pori yang dihasilkan pun termasuk material mesopori yang memiliki ukuran diameter $2 \mathrm{~nm}-50 \mathrm{~nm}$.

2. Penambahan template OA (Octyl Amine) pada silika hasil sintesa dari sekam padi berhasil dilakukan untuk menghasilkan mesoporous silika nanopartikel yang berbentuk lebih homogen dengan ukuran partikel sebesar $16 \mathrm{~nm}-40 \mathrm{~nm}$. Hal ini menunjukkan bahwa material silika yang dihasilkan merupakan nanomaterial, akan tetapi belum berhasil membentuk hollow mesoporous silika nanopartikel. Karena pada proses etching yang kurang merata pada template sehingga rongga mengecil, yang menyebabkan pembentukan hollow mesoporousnya kurang nampak.

\section{UCAPAN TERIMA KASIH}

Penulis mengucapkan terima kasih kepada Program Dana Penelitian Jurusan tahun 2018.

\section{DAFTAR PUSTAKA}

[1] E. . Johansson, "Controlling the pore size and morphology of mesoporous silica," Linköping University, 2010.

[2] Nandiyanto, "Design a highly ordered and uniform porous structure with multisized pores in film and particle forms using a template-driven self-assembly technique," Acta Mater., pp. 282-289, 2008.

[3] F. Kleitz, "Ordered mesoporous materials: template removal, frameworks, and morphlogy," Ruhr-Universität Bochum, Saverne, 2002.

[4] Roth, "Characterization of mesoporous molecular sieves differences between M41S and pillared layered zeolites," Stud. Surf. Sci. Catal., pp. 501-508, 2000.

[5] M. P. Prawingwong, "Mesoporous silica synthesized from rha and its grafting with ph-responsive poly(acylic acid)," Thammasat University, Thailand, 2011.

[6] J. . Vartuli, "Development of A Formation Mechanism for M41S Materials," Stud. Surf. Sci. Catal., vol. 84, pp. 53-60, 1994.

[7] J. Armesto, L., Bahillo, A., Veijonen, K., Cabanillas, A., \& Otero, "Combustion Behaviour of Rice Husk in a Bubbling Fluidised Bed. Biomass and Bioenergy," pp. 171 - 179, 2002.

[8] A. Barrabino, "Synthesis of mesoporous silica particles with control of both pore diameter and particle size," 2011. 